\title{
Two Old Nubian Inscriptions from Akasha West
}

\author{
Vincent W.J. van Gerven OeI, Adam ŁaJtar
}

\begin{abstract}
The present paper analyses two Old Nubian inscriptions found at a church in Akasha West in 1969. The first inscription was found on an ostracon and invokes Jesus Christ. The second inscription was found on the altar inside the church's sanctuary, and refers to the Holy Altar of Michael. The publication gives a description of the inscription, a transcription with critical apparatus, and a grammatical and general commentary on the text.
\end{abstract}

Keywords: Christian Nubia, Akasha West, Old Nubian, ostracon, altar

Vincent W.J. van Gerven Oei, independent researcher, The Hague; vincent@vangervenoei.com;

(iD) $0000-0003-1637-4261$

Adam Łajtar, Institute of Archaeology, University of Warsaw, Warsaw; a.lajtar@uw.edu.pl;

(D) $0000-0003-3842-2180$

The following two Old Nubian texts were discovered respectively in Rooms 4 and 46 (Sanctuary) of the church (Rooms 1-4, 45-46) at the northern end of a fortified settlement at Akasha West (Figs 1-2). The site was initially registered in April 1964 during Sudan Antiquities Service's reconnaissance survey from Gemai to Dal directed by Anthony James Mills as [21-N-11], a 'stone-built Christian fort'. ${ }^{1}$ James Knudstad supervised the excavation work at the site between March and April 1969, and considered it a monastery, as also reported by Jean Leclant. ${ }^{2}$ David Edwards suggests that the 'unusual form' of the 'small church' was the result of a series of 'significant modifications' to the building. ${ }^{3}$ Jacques van der Vliet has identified an inscribed ceramic basin with a fish motif found at the same site as being dedicated to Saint Epimachos, which he suggests could be 'the name

\footnotetext{
1 Mills 1965: 10.

2 Leclant 1971: 249.

3 Edwards 2019: 57.
} 

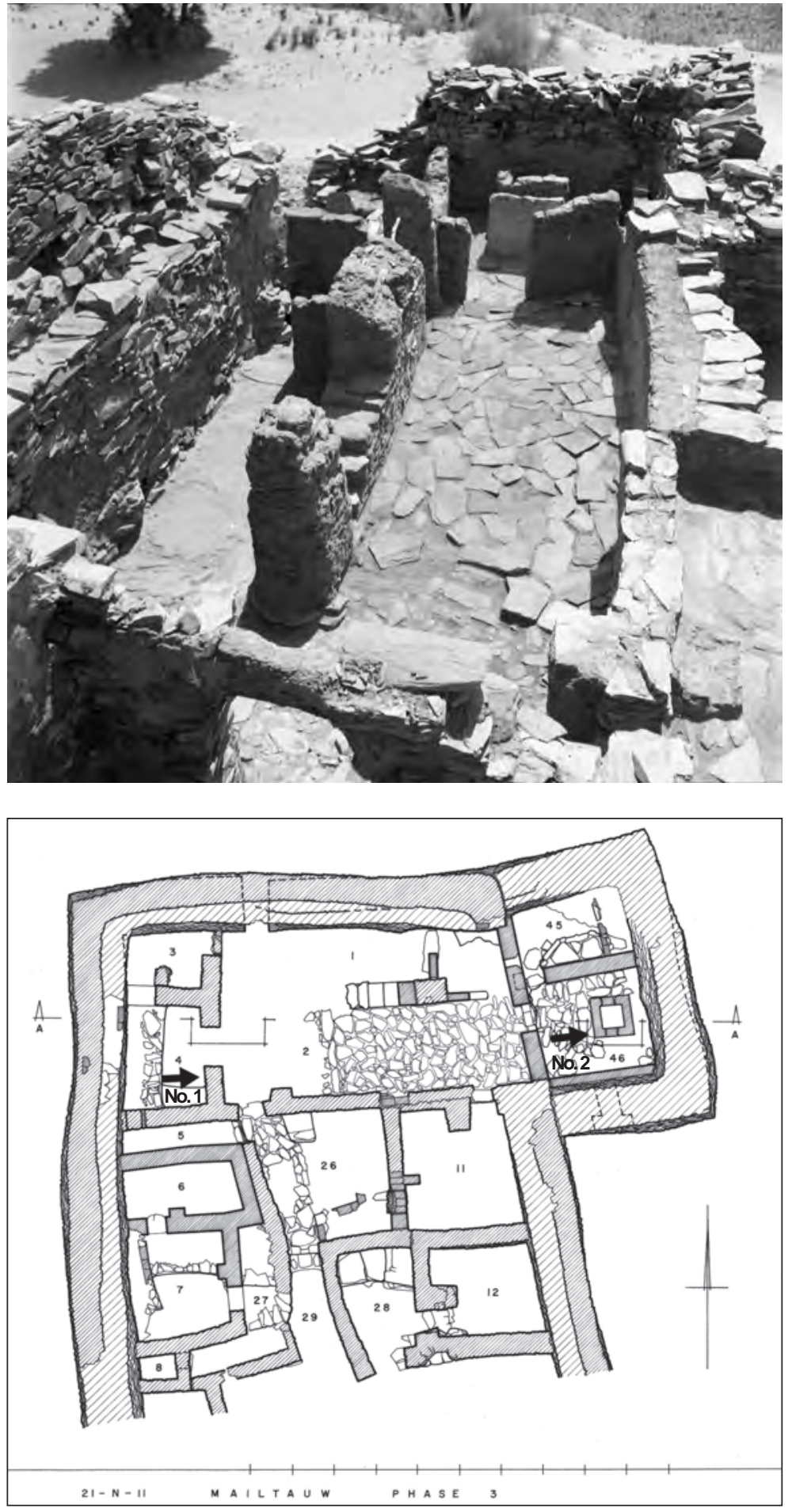

1. Late phase of church within [21-N-11] with paved floor and altar in sanctuary beyond (@ ASSN archive, photo F/613:3).

2. Plan of (late) phase 3 of church within [21-N-11]; location of the ostracon (no. 1) and the altar with the inscription (no. 2) marked with arrows (@ ASSN archive; drawing: J.E. Knudstad, 1969; courtesy of D. Edwards). 
3. Ostracon from [21-N-11] ( ASSN archive).

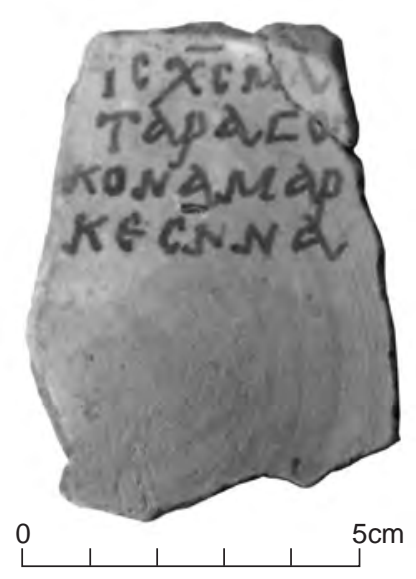

of the church or monastery to which the basin was donated'. ${ }^{4}$ The presence of a church is confirmed by the local toponym Kisseentawwo 'below the church (ruin)', ${ }^{5}$ which still refers to the site in which the inscriptions were found.

\section{OSTRACON}

The ostracon (Fig. 3) was found with its written face oriented downward in the fabric of the eastern wall of Room 4 of the church, on the south side of the doorway, at the level of its lintel. ${ }^{6}$ Room 4 was accessible from the body of the church through a door from Room 2. The room contained two mastaba benches, and its walls, replastered three times, were covered by painted decorations. ${ }^{7}$ The ostracon has 4 lines in black ink on the outside of a sherd, executed in a neat and regular hand. Even though the text is in Old Nubian, it is not executed in Nubian-type majuscules. The script is very particular, with some letters written upright while others look like inclined majuscules, with pronounced one-sided serifs on the kappa, alpha, mu, and $n u$. The text is clearly readable from the photograph and complete. The current location of the object is unknown.

\section{Transcription:

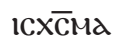 \\ тарагос \\ KONAMAP \\ 4 кеC̄NNa}

${ }^{4}$ Van der Vliet 2003: 83-84 (no. 24).

${ }^{5}$ Bell 1970: 72, no. 140201.

${ }^{6}$ Edwards 2019: 66. It is impossible to know whether the ostracon was deposited there on purpose, e.g. for apotropaic reasons, or if was placed accidentally, as part of the mortar filling the space between bricks. The second possibility seems more probable to us.

${ }^{7}$ Edwards 2019: 58. 
Reading text:

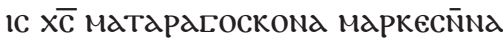

Translation:

Jesus Christ. Helyou has become a witness. Helyou stole.

Commentary:

After the invocation of Jesus Christ in line 1 ıc $x \overline{\mathrm{c}}$, we find two verbal forms.

1. ıxx : Nomen sacrum for Jesus Christ. The horizontal stroke above ic marking it as a nomen sacrum is effaced together with the upper part of $\mathrm{\imath}$.

1-3. матар-дL-оc-ко-N-a witness-become-ASP-PERF-PRS.2/3SG-PRED, 'He has become (fully) a witness'. The aspect marker -oc has a variable meaning dependent on the meaning of the verbal root it is attached to. It often appears to indicate a sense of completion, as in $\mathbf{a} \gamma \lambda$-oc, 'to save completely'. The presence of perfect tense marker -кo is very rare in Old Nubian literary texts and may be either a reflex of the spoken language (modern Nile Nubian -ko as regular past tense morpheme). It may therefore be an indication that the text should be dated relatively late. MaTap 8 is generally used for witnesses in legal documents, but has also been attested in a visitor's graffito in a commemorative complex of the monastery on Kom $\mathrm{H}$ in Dongola, probably as an expression of admiration by an eyewitness. ${ }^{9}$

3-4. марк-ес-N̄N-d steal-PFV.PST2-PRS.2/3SG-PRED, 'He stole'. This verb Mapk has not been previously attested, but most probably related to the Nobiin verb mark 'to steal'.$^{10}$ The combination of the past 2 tense with the present tense morpheme is uncommon, but the tense system underwent a rather dramatic transformation in the development from Old Nubian to contemporary Nobiin. Both verbal forms on this ostracon may be a testimony to that.

The referentiality of the two verbs is unclear. Without further context it is impossible to judge whether a second or third person subject is implied, and whether both verbs in fact have the same subject. It cannot be ascertained whether the text referred to a real-life situation or played with a literary motif.

\section{PRAYER ON AN ALTAR}

The altar was located in Room 46 of the church. The altar was constructed from mud-brick with mud plastering, without a surviving altar top. ${ }^{11}$ The upper-right corner of the front

\footnotetext{
8 Browne 1996: 112.

${ }^{9}$ Łajtar, Van der Vliet 2017: 28 (no. VIII).

10 Reinisch 1879: 110.

11 Edwards 2019: 59.
} 
4. Detail of the altar in Room 46 of church within [21-N-11] (C) ASSN archive, photo ASSN F/613:11).

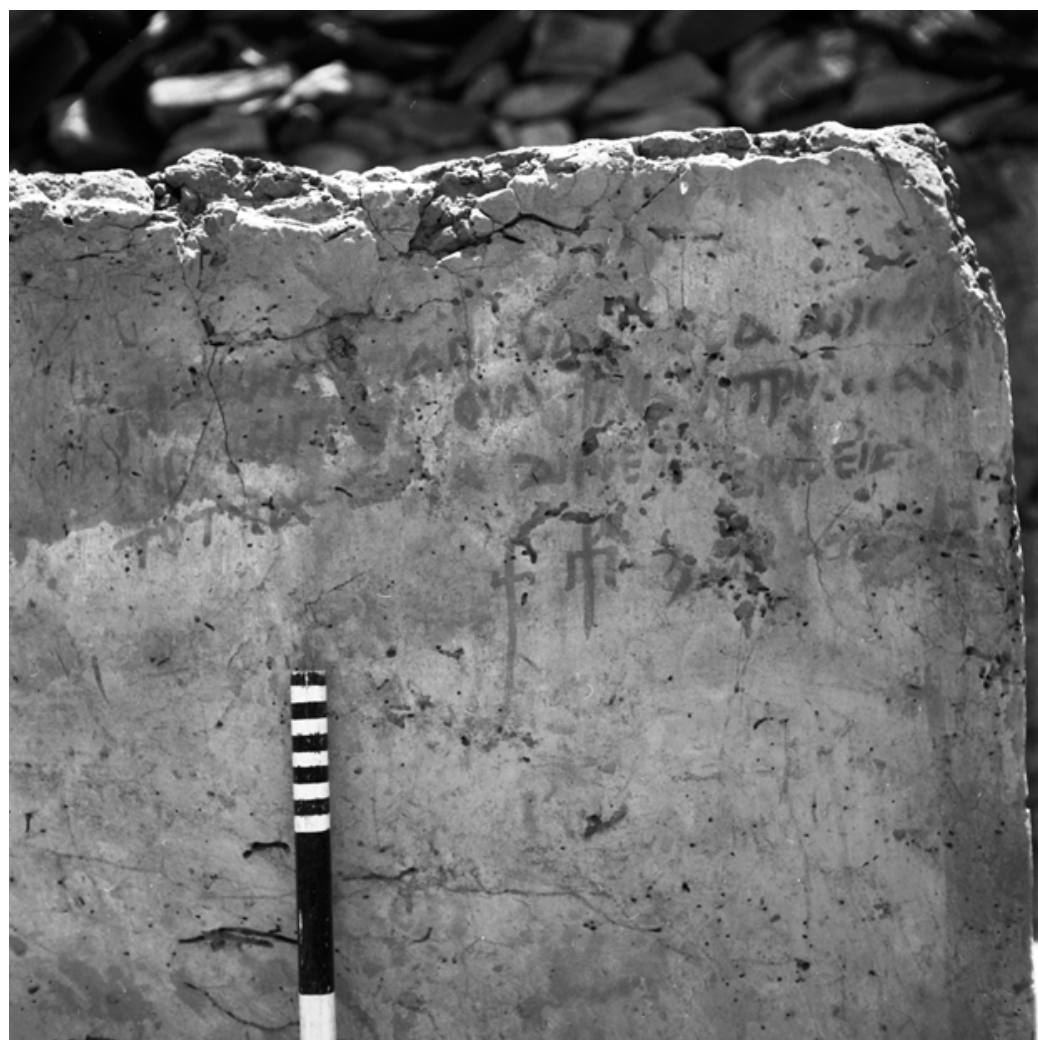

of the altar featured an inscription (Fig. 4) of 4 lines in red ink, written in Nubian-type majuscules executed in an uneven hand. No other Old Nubian inscriptions of this length have been found on altars. The usage of red ink is very rare in wall inscriptions, for which black ink is the norm. Because of the lack of comparative material, it is impossible to assert whether the red ink is used because the writing is on an altar, or because of another reason. The text has significantly faded. Leclant first reported its discovery during work by Mills, Knudstad, and Lars E.I. Gezelius in the Batn el-Hajjar between October 1968 and May 1969: Trois grandes forteresses de pierre se dressent sur la rive Ouest d'Ukma. La plus au Sud semble avoir correspondu à un monastère: on y a trouvé les ruines d'une petite église de briques avec un autel également en briques qui portait une longue inscription en vieux nubien..$^{12}$ According to David Edwards, the front of the altar was consolidated in mid-May 1969 and transported to Khartoum, but its current whereabouts are unknown. Therefore, the authors relied solely on photographic material shot during the excavation for the transcription.

${ }^{12}$ Leclant 1971: 249. 
Transcription:

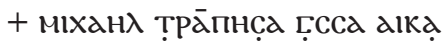

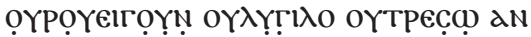

TотTа $\triangle \ldots$ a AINeç emolY/ eїгат . I H

$+\mathrm{R} \ldots \mathrm{Te} \Delta \cdot d$

Translation:

Holy Altar (of) Michael,

put me in the ear of the kings,

(...) my son to/for me.

I Eingat() (...) Priest (...)

\section{Commentary:}

The text exhibits the essential properties of a prayer, including the invocation of the Holy Altar of Michael (line 1), the request with the imperatives ortpeç̣ (line 2) and $\Delta$ Ineç̣ (line 3), and the mention of the beneficiary (lines 3-4). Both the request and the mention of the beneficiary are not entirely clear due to the damage of the text; for some thoughts see the line commentary. From the formal point of view the text resembles mementos left by visitors on the walls of cult places in Christian Nubia. This suggests that it is a secondary addition to the church space and not an element of the original installation. The honourable location of the inscription on the church altar may be connected with the fact that its author was a priest, perhaps the main priest of the church. The fact that the inscription invokes Archangel Michael seems to suggest that the Church was dedicated to Michael; Michael was an important figure in Nubian Christianity, and frequently appealed to. ${ }^{13}$

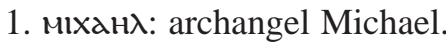

трд̄пнс̣ג: трд̄пнс, ‘altar’ from Greek $\tau \rho \alpha ́ \pi \varepsilon \zeta \alpha,{ }^{14}$ ending in predicate marker -ג.

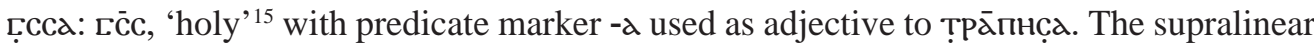
stroke over the first sigma is no longer visible or had been omitted by the scribe. The

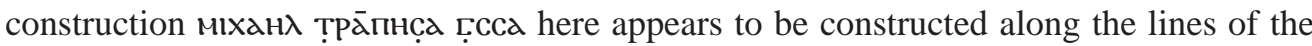

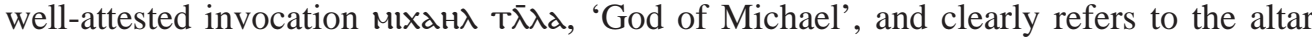
on which the inscription has been written. Such an invocation is unparalleled in Christian Nubia but has been attested in Sahidic Coptic rent receipt written on papyrus: ח.АIKaıon м̣пөүсүастнріом єтоүадв фагіос гесрге, 'The dikaion of the holy altar of George'

\footnotetext{
${ }^{13}$ For an overview of the cult of Archangel Michael in Christian Nubia, see: Gilhus, Tsakos, Wright 2019.

14 Browne 1996: 175.

${ }^{15}$ Browne 1996: 200.
} 
(P.Ryl.Copt 181) ${ }^{16}$ It might be explained by the fact that the altar (and the entire church) was dedicated to the Archangel Michael, who functioned as an intermediary between man and God. This then also implies that the monastery, and not the church, should be identified with Saint Epimachus.

dıkạ: accusative of first singular pronoun. Probably the object of 2. oүтрєç⿻.

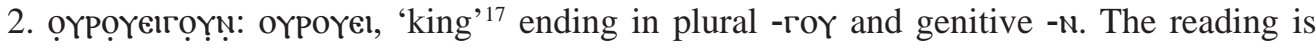
tentative, but no other attested noun appears to fit. The gamma strongly suggests a plural

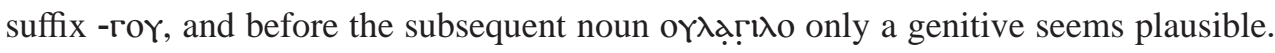

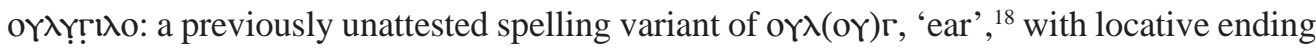

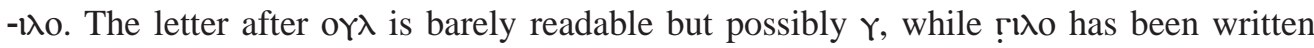
with a considerably taller letter than the first part of the word. The phrase ợpợerго oy $\lambda$ Y written on an altar, there are two possible referents: heavenly kings, implying either the Trinity or those Makuritan kings, which are frequently depicted under the guardianship of archangels, already ascended to heaven, or earthly kings, in which case God is asked, through the intercession of Michael, on whose altar the prayer is written, to put in the ears of the kings of Makuria the person and the case of the author. If indeed the kings referred to are earthly, the plural could indicate here that there were at least two rulers with the title orpores present at the same moment.

оүтрес̣: оүтр, 'to put, lay’19 with imperative second/third singular ending -e-c̣.̣.

aN: genitive of first singular pronoun.

3. тоттג: тот, 'son' ${ }^{20}$ with accusative $-\mathrm{kd}$, progressively assimilated to $-\mathrm{Td}$, object of 3. $\Delta$. . a $\Delta$ Ineç. This type of assimilation is not attested in literary Old Nubian, which consistently has тотка. However, assimilated forms such as тоттג are attested in Nobiin. ${ }^{21}$ This may suggest a relatively late dating of the text. A similar phrase, an ToTTd caela Aineco 'save my son for me', has been found at Banganarti in an inscription of a rather late date (end of the thirteenth/first half of the fourteenth century). ${ }^{22}$

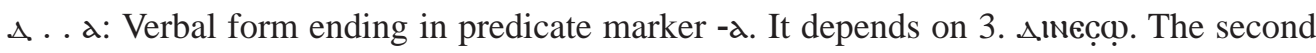
letter is completely illegible, while the third letter perhaps has a vertical descender

\footnotetext{
16 Crum 1909: 92-93 (no. 181).

17 Browne 1996: 140.

18 Browne 1996: 136.

19 Browne 1996: 141.

20 Browne 1996: 180.

21 Werner 1987: 98.

22 Łajtar forthcoming: no. 309.
} 
(perhaps a p?). There are also traces of a possible supralinear stroke above the first or first and second letters.

AINeç: $\Delta$ IN, 'to give (to me)', ${ }^{23}$ with imperative second/third singular ending -€-çu. Here

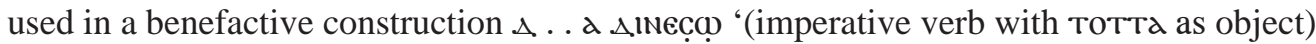
to/for me' ${ }^{24}$

emoly/: Greek pronoun 'I', often used in visitor inscriptions. ${ }^{25}$ What follows must be the name of the author of the text.

єїгdT . н: This is expected to be a proper name. No proper names beginning with eïгdThave been attested.

\section{Acknowledgments}

The authors would like to thank David N. Edwards for permission to publish these texts and their photographic documentation. He also kindly provided us with notes compiled on the basis of field records from Anthony J. Mills and James E. Knudstad.

\section{References}

Bechhaus-Gerst, M. 2011: The (Hi)story of Nobiin: 1000 Years of Language Change, Frankfurt a/Main

Bell, H. 1970: Place Names in the Belly of Stones, Linguistic Monograph Series 5, Khartoum Browne, G.M. 1996: Old Nubian Dictionary, CSCO 556, Subsidia 90, Leuven

Crum, W.E. 1909: Catalogue of the Coptic Manuscripts in the Collection of the John Rylands Library Manchester, Manchester

Edwards, D.N. 2019: A Possible Monastery and the ‘Upper Maqs’ at Ukma-Akasha West?, EtudTrav XXXII, 53-79

Gilhus, I.S., Tsakos, A., Wright, M.C. 2019: The Archangel Michael in Africa: History, Cult and Persona, London

Leclant, J. 1971: Fouilles et travaux en Égypte et au Soudan, 1969-1970, Orientalia 40/2, 224-266

Łajtar, A. forthcoming: The Late Christian Pilgrimage Centre at Banganarti: The Evidence of Inscriptions, JJP-Suppl., Warsaw

Łajtar, A., Vliet, J. van der 2017: Empowering the Dead in Christian Nubia. The Texts from a Medieval Funerary Complex in Dongola, JJP-Suppl. XXXII, Warsaw

Mills, A.J. 1965: The Reconnaissance Survey from Gemai to Dal: A Preliminary Report for 1963-64, Kush XIII, 1-12

\footnotetext{
23 Browne 1996: 42.

24 Bechhaus-Gerst 2011: 142-147.

25 See: Łajtar forthcoming.
} 
Reinisch, L. 1879: Die Nuba-Sprache, Vienna

Vliet, J. van der 2003: Catalogue of the Coptic Inscription in the Sudan National Museum at Khartoum (I. Khartoum Copt.), OLA 121, Leuven

Werner, R. 1987: Grammatik des Nobiin (Nilnubisch): Phonologie, Tonologie und Morphologie, Hamburg 


\section{ÉTUDES et TRAVAUX XXXII / 2019}

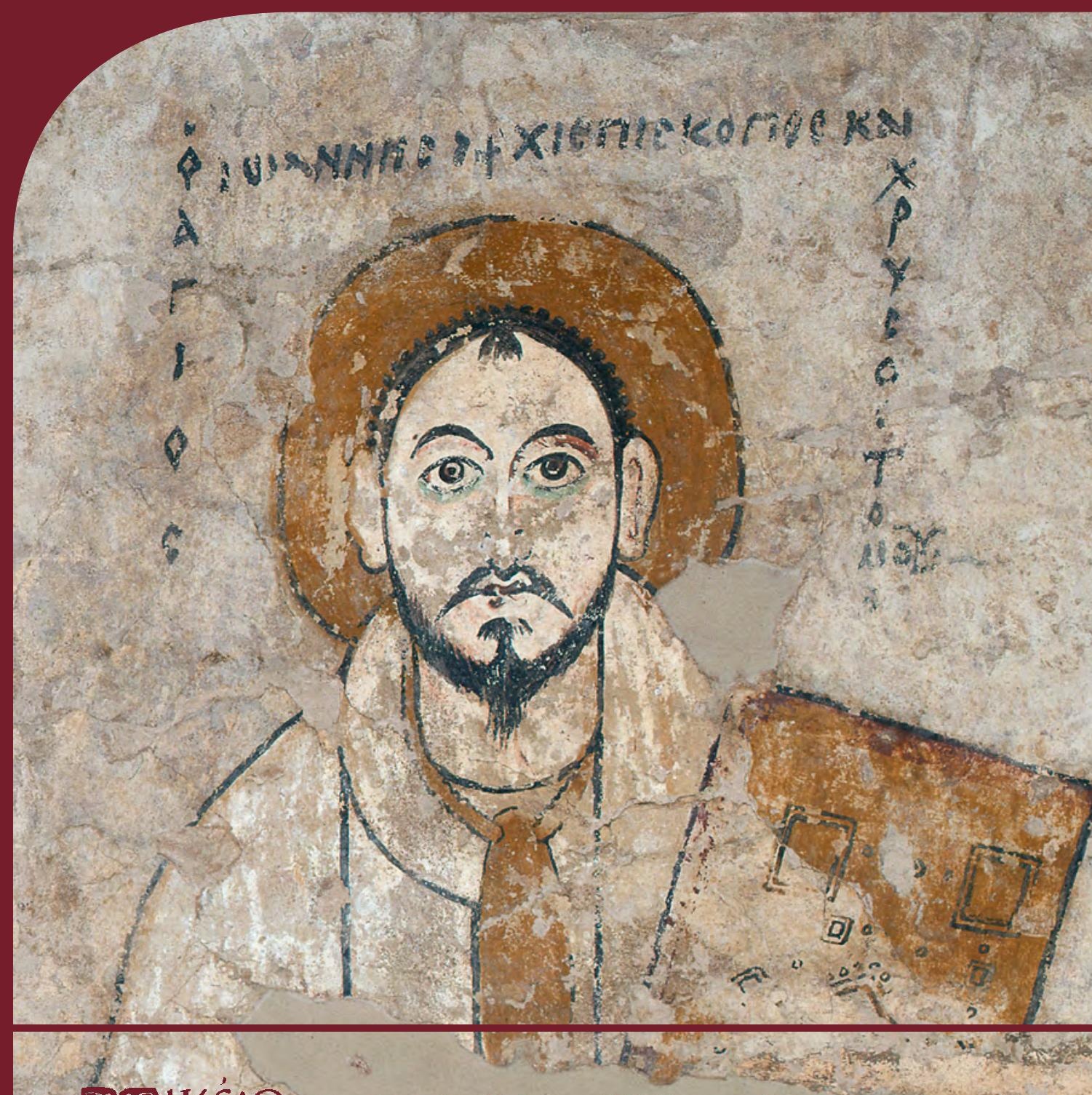

BOMIKSiO Institut des Cultures Méditerranéennes et Orientales ED2A PAN de l'Acácémie Polonaise des Sciences 


\title{
COMITÉ DE RÉDACTION SCIENTIFIQUE
}

Maciej Makowski - rédacteur en chef Jadwiga Iwaszczuk - rédacteur

Maciej G. Witkowski - rédacteur

Agnieszka Ryś - sécretaire de la rédaction

Bogdan Żurawski - rédacteur thématique du volume

CONSEIL SCIENTIFIQUE DU JOURNAL

M. Kobusiewicz (IAE PAN, Warszawa), E. Laskowska-Kusztal (IMOC PAS, Warszawa),

D. Michaelides (University of Cyprus, Nicosia),

J.Ch. Moretti (IRAA-MOM, Université de Lyon 2/CNRS),

D. Raue (Ägyptisches Museum der Universität Leipzig), P. Reynolds (ICREA, España),

D. Welsby (British Museum, London)

\section{COMITÉ SCIENTIFIQUE DE LECTURE}

D.E. Arnold (Wheaton College/The Field Museum, Chicago), H.D. Baker (University of Toronto),

P. Ballet (ArScAn-ESPRI, Université Paris Nanterre), Ch. Barber (Princeton University),

N. Beaux-Grimal (IFAO, Caire/Collège de France, Paris), A. Boud'hors (CNRS, IRHT, Paris),

J. Budka (Ludwig-Maximilians-Universität München), R. David (SFDAS),

A. Delattre (CPEG, Bruxelles), A. Dodson (University of Bristol),

E. Fogliadini (Facoltà Teologica dell'Italia Settentrionale, Milan),

V. Francigny (CNRS/CRES, Paris), L. Gabolde (CNRS), C. Gobeil (Egypt Exploration Society, London),

N. Hamdi (UCL, Louvain), J. den Heijer (CIOL/INCAL, Louvain-la-Neuve),

S. Ikram (American University in Cairo), Ch. Leitz (Universität Tübingen), S. Ortisi (Universität München),

E. Rova (Università Ca' Foscari Venezia), G. Ruffini (Fairfield University),

A. Sasson (San Diego Natural History Museum), H. Satzinger (Universität Wien),

S.M. Schellinger (The Ohio State University, Columbus), G. Schreiber (Eötvös Loránd University, Budapest),

E. Teeter (University of Chicago), S. Torallas-Tovar (University of Chicago),

Y. Tristant (Macquarie University, Sydney), V. Vaelske (independent researcher),

H. Vymazalová (Charles University, Prague), P. Weschenfelder (Universität Wien),

B. Williams (University of Chicago/PCMA UW, Warszawa),

K. Winther-Jacobsen (The Danish Institute at Athens), E. Zacharopoulou (University of Johannesburg),

P. Grotowski (UPJPII, Kraków), E. Papuci-Władyka, J. Śliwa (IA JU, Kraków), A. Ćwiek (IA AMU, Poznań),

K.O. Kuraszkiewicz, M. Pinker (FOS UW, Warszawa), Ł. Niesiołowski-Spanò (IH UW, Warszawa),

M. Gawlikowski, Mahmoud El-Tayeb (PCMA UW, Warszawa), S. Rzepka (IA UW, Warszawa)

\author{
RÉDACTION TECHNIQUE \\ Monika Wesołowska
}

REVUE DES TEXTES ANGLAIS

Jo Harper 
ÉTUDES et TRAVAUX

XXXII 
INSTYTUT KULTUR ŚRÓDZIEMNOMORSKICH I ORIENTALNYCH POLSKIEJ AKADEMII NAUK

\title{
STUDIA i PRACE
}

\author{
XXXII
}

gू IKŚiO

ESAN

WARSZAWA

2019 
INSTITUT DES CULTURES MÉDITERRANÉENNES ET ORIENTALES DE L’ACADÉMIE POLONAISE DES SCIENCES

\section{ÉTUDES et TRAVAUX}

XXXII

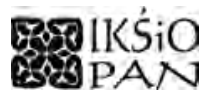

VARSOVIE

2019 
Publication scientifique financée dans le cadre du programme du Ministre de la Science et de l’Éducation Supérieure

« Programme National de Développement de l’Humanistique » pour les années 2016-2021 (projet no $3 b H 150099$ 83)

\title{
TI NARODOWY PROGRAM ROZWOJU HUMANISTYKI
}

\author{
Copyright $(\mathbb{C}$ \\ Instytut Kultur Śródziemnomorskich i Orientalnych PAN \\ et les Auteurs \\ Warszawa 2019
}

\begin{abstract}
ISSN 2084-6762
(avant 2011 : 0079-3566)

e-ISSN 2449-9579

Version première en papier, imprimée en Pologne - 150 copies

Version électronique accessible sur

http://www.etudesettravaux.iksiopan.pl
\end{abstract}

Édition: Polskie Towarzystwo Historyczne et Wydawnictwo Neriton, Warszawa

Conception générale de couverture : J. Iwaszczuk

Photo de couverture : P. Ligier ; courtoisie du Musée National de Varsovie

(Saint Jean Chrysostome, peinture, cathédrale de Faras). 


\section{Table des matières}

Editorial: Quid novi ex Nubia (par Bogdan Żurawski) ............................................... 7

Bibliography of Professor Stefan Jakobielski ................................................................ 13

Aneta Cedro, Bogdan Żurawski

Living with the Past in Modern Sudanese Village. Traditional Pottery Production

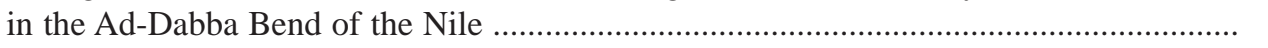

DAVID N. EDWARDS

A Possible Monastery and the 'Upper Maqs’ at Ukma-Akasha West? ............................ 53

Vincent W.J. van GeRven OeI

An Old Nubian Curse from the Faras Cathedral ........................................................ 81

Vincent W.J. van Gerven Oei, Adam Łajtar

Two Old Nubian Inscriptions from Akasha West ........................................................ 89

Vincent W.J. van Gerven Oei, Alexandros Tsakos

Rubrication Patterns in Two Old Nubian Manuscripts from Serra East .......................... 99

KAREL C. INNEMÉE

A Man in a Vessel, Once More .................................................................................. 111

KAREL C. INNEMÉE, Dobrochna ZielińSKA

Faces of Evil in Nubian Wall-Painting - An Overview ................................................ 121

ADAM ŁAJTAR

Epitaph of Merki Found in Hambukol ....................................................................... 145

MAGDALENA ŁAPTAŚ

Attributes, Vestments, Context and Inscription in the Identification of Nubian

Paintings: Proposing the 'Multi-Layer' Image Recognition Method ............................... 161

Grzegorz Ochala

Nubica Onomastica Miscellanea I: Notes on and Corrections to Personal Names

Found in Inscriptions from Faras 


\section{Robin SEIGNOBOS}

L'influence du Kitāb ahbār al-Nūba d'Ibn Sulaym al-Uswānī sur l'Histoire des églises et monastères d'Égypte d'Abū al-Makārim

JACQUES VAN DER VLIET

Exit Bishop Tamer - the Sequel. A New Edition of the Epitaph of Papsine alias Doulista (DBMNT 78) 